\title{
SYTUACJA PROCESOWA OSKARŻYCIELA SUBSYDIARNEGO - PRÓBA OCENY SKUTECZNOŚCI OCHRONY PRAW POKRZYWDZONEGO W ŚWIETLE PRZEPISÓW KODEKSU POSTĘPOWANIA KARNEGO I JEGO NOWELIZACJI
}

\section{Oskarżyciel subsydiarny jako problem procesowy - uwagi wprowadzające}

Prawo wniesienia przez pokrzywdzonego posiłkowego aktu oskarżenia i realizacja funkcji oskarżania stanowi wyłom od istoty i zasad publicznoskargowego trybu ścigania ${ }^{1}$. Konsekwencją wyjątkowości takiego uprawnienia jest m.in. procedura prowadząca do jego nabycia, która jest elementem systemu gwarancji przestrzegania zasady legalizmu² oraz stanowi realizację konstytucyjnego prawa do sądu³. Z drugiej strony uprawnienia takie muszą być wprowadzane rozważnie, aby nie doszło

\footnotetext{
* Dr hab., Uniwersytet Warmińsko-Mazurski w Olsztynie; e-mail: justyna.karazniewicz@ uwm.edu.pl, https:/ / orcid.org/0000-0003-2276-6640.

1 Por. R.A. Stefański, Z. Gostyński, w: Kodeks postępowania karnego. Komentarz, t. 1, red. J. Bratoszewski, L. Gardocki, Z. Gostyński, S.M. Przyjemski, R.A. Stefański, S. Zabłocki, Warszawa 2003, s. 457; S. Stachowiak, A. Gerecka-Żołyńska, P. Libertowski, M. Żbikowska, Uwagi o trybach ścigania przestępstw w polskim postępowaniu karnym, w: Z problematyki funkcji procesu karnego, red. T. Grzegorczyk, J. Izydorczyk, R. Olszewski, Warszawa 2013, s. 128-137; T. Grzegorczyk, Tryby ścigania karnego, w: System Prawa Karnego Procesowego, t. 1. Zagadnienia ogólne, red. P. Hofmański, Warszawa 2013, s. 286-364.

2 Np.: J. Tylman, Zasada legalizmu w procesie karnym, Warszawa 1965, s. 74-75; S. Waltoś, Nowe instytucje w kodeksie postępowania karnego z 1997 roku, Państwo i Prawo 1997, nr 8, s. 37-38; M. Rogacka-Rzewnicka, Oportunizm i legalizm ścigania przestępstw w świetle wspótczesnych przeobrażeń procesu karnego, Warszawa 2007, s. 83.

3 Por. Ł. Supera, D. Wyszkowski, Subsydiarny akt oskarżenia w ujęciu konstytucyjnym,
} Palestra 2016, nr 7-8, s. 70-75; P. Wiliński, Proces karny w świetle Konstytucji, Warszawa 2011, 
do nadmiernej „prywatyzacji” postępowania karnego tam, gdzie ustawodawca nakazuje ściganie i oskarżanie $\mathrm{w}$ interesie publicznym ${ }^{4}$. O wciąż aktualnych wątpliwościach w odniesieniu do tego zagadnienia świadczą liczne zmiany regulacji oskarżenia subsydiarnego ${ }^{5}$, na czele z projektami usunięcia tej instytucji z polskiego porządku prawnego ${ }^{6}$. Jest to instytucja bardzo złożona, jednak z uwagi na ograniczony zakres opracowania warto spojrzeć na najważniejsze elementy tej konstrukcji z pewnej perspektywy czasowej i spróbować odpowiedzieć na pytania co do przyjętej polityki legislacyjnej i realności ochrony interesów pokrzywdzonego, zwłaszcza $w$ odniesieniu do zmian wprowadzonych $w$ tym zakresie nowelą z dnia 19 lipca 2019 r. ${ }^{7}$

s. 230-232; M. Rogalski, Procesowe gwarancje zasady legalizmu, w: Zasada legalizmu w procesie karnym, t. 1, red. B. Dudzik, J. Kosowski, I. Nowikowski, Lublin 2015, s. 379.

4 Wątpliwości te związane są także z zaangażowaniem emocjonalnym pokrzywdzonego i brakiem obiektywizmu z jego strony. Por. np. J. Grajewski, Sądowa ingerencja w postępowanie przygotowawcze, w: Nowa kodyfikacja karna. Kodeks postępowania karnego. Krótkie komentarze, Warszawa 1998, z. 8, s. 18; J. Grajewski, S. Steinborn, w: Kodeks postepowania karnego, t. 1. Komentarz do art. 1-424, red. L.K. Paprzycki, Warszawa 2013, s. 246.

5 O regulacjach wcześniejszych polskich kodeksów w tym zakresie zob. m.in.: W. Sych, Wptyw pokrzywdzonego na tok postępowania przygotowawczego w polskim procesie karnym, Zakamycze 2006, s. 197, 207; R. Kmiecik, Oskarżyciel posiłkowy w procesie karnym, Warszawa 1977, s. 15; T. Grzegorczyk, Kodeks postępowania karnego. Komentarz, Kraków 2003, s. 222; P. Rogoziński, Kilka uwag na temat przestanek wniesienia subsydiarnego aktu oskarżenia de lege lata i de lege ferenda, w: Z problematyki funkcji..., s. 46-47; E. Kruk, Skarga oskarżycielska jako przejaw realizacji prawa do oskarżania uprawnionego oskarżyciela w polskim procesie karnym, Lublin 2016, s. 266.

6 Por. uzasadnienie rządowego projektu ustawy o zmianie ustawy o prokuraturze oraz niektórych innych ustaw z dnia 2 listopada 2006 r., Druk nr 1113, http:/ / orka.sejm.gov.pl/ proc5.nsf/opisy/1113.htm, w którym podkreślano niską skuteczność i rzadkie wykorzystywanie tego uprawnienia przez pokrzywdzonych. Ostatecznie wycofano się z propozycji usunięcia art. 55 Kodeksu postępowania karnego (dalej: K.p.k.) „ze względów społecznych” (zob. Sprawozdanie z posiedzenia Komisji Sprawiedliwości i Praw Człowieka w dniu 13.02.2007 r., http:/ / orka.sejm.gov.pl/Biuletyn.nsf/wgskrnr5/SPC-92).

7 Ustawa z dnia 19 lipca 2019 r. o zmianie ustawy - Kodeks postępowania karnego oraz niektórych innych ustaw, Dz. U. z 2019 r. poz. 1694, weszła w życie w dniu 5 października 2019 r. 


\section{Procedura prowadząca do uzyskania uprawnienia do wniesienia subsydiarnego aktu oskarżenia}

Procedura prowadząca do uzyskania uprawnień oskarżyciela subsydiarnego opiera się na poddaniu kontroli decyzji o zaniechaniu ścigania ${ }^{8}$ (postanowienia o odmowie wszczęcia albo o umorzeniu śledztwa lub dochodzenia) $)^{9}$ W obecnie obowiązującym stanie prawnym analiza zasadności takiej decyzji dokonywana jest przez trzy podmioty. Pierwszym $\mathrm{z}$ nich jest prokurator, który wydał lub zatwierdził postanowienie o umorzeniu śledztwa albo dochodzenia, zaskarżone przez pokrzywdzonego. Z uwagi na względną dewolutywność zażalenia prokurator taki może je rozpoznać i uznać za zasadne w całości w trybie tzw. autokontroli ${ }^{10}$, bez potrzeby przekazywania zażalenia sądowi ${ }^{11}$. W przypadku nieuwzględnienia zażalenia przez organ ad quo, kontrola zasadności decyzji o zaniechaniu ścigania dokonywana jest przez sąd właściwy do rozpoznania sprawy, do którego kierowane jest nieuwzględnione przez prokuratora

8 Liczba składanych zażaleń na decyzje o zaniechaniu ścigania wzrasta. W 2016 r. złożono 52343 zażaleń, w 2017 r. już 70 009, zaś w 2018 r. - 72 508. Zob. coroczne Sprawozdania Prokuratury Krajowej z działalności powszechnych jednostek organizacyjnych prokuratury w sprawach karnych, https://pk.gov.pl/dzialalnosc/sprawozdania-i-statystyki/

9 Dla większej przejrzystości tekstu w dalszych rozważaniach posłużono się odniesieniem do postanowienia o umorzeniu, z zastrzeżeniem, że dotyczą one także drugiej ze wskazanych decyzji.

10 Prokurator w trybie tzw. autokontroli uwzględnia ok. 7-8\% skierowanych zażaleń na wydaną przez niego decyzję o zaniechaniu ścigania. Dane na podstawie corocznych Sprawozdań Prokuratury Krajowej.

11 Por. także pogląd, że w przypadku tych decyzji względna dewolutywność zażalenia powinna być wyeliminowana z uwagi na oddalenie w czasie możliwości wniesienia skargi subsydiarnej. R. Kmiecik, O przyczynach i skutkach kasacji Prokuratora Generalnego z powodu braku skargi uprawnionego oskarżyciela, Prokuratura i Prawo 2014, nr 1, s. 6-7; H. Paluszkiewicz, M. Błaszyk, A. Łakomy, M. Żbikowska, Prawne zabezpieczenia przestrzegania zasady legalizmu. Zagadnienia wybrane, w: Zasada legalizmu w procesie karnym, t. 1, s. 300. Zob. także uwagi na temat praktyki organów ścigania, z których wynika, że w wielu wypadkach prokurator zamiast uchylać zaskarżone postanowienie albo przesłać je niezwłocznie do sądu, prowadzi czynności wnioskowane przez stronę albo podejmuje inne czynności z urzędu, co słusznie uznaje się za sprzeczne z regulacjami K.p.k. Szerzej K. Rydz-Sybilak, Zasada legalizmu w praktyce organów procesowych a uprawnienia pokrzywdzonego w postępowaniu przygotowawczym, w: Zasada legalizmu w procesie karnym, t. 1, s. 387-392. 
zażalenie $^{12}$. W razie uchylenia przez sąd postanowienia o umorzeniu i przekazania sprawy prokuratorowi oraz wydania przez niego ponownego postanowienia o umorzeniu, kolejne zażalenie pokrzywdzonego na taką decyzję powoduje zaangażowanie w kontrolę trzeciego podmiotu, a mianowicie prokuratora nadrzędnego nad tym, który wydał zaskarżoną decyzję.

W tym miejscu należy zwrócić uwagę na fakt, iż w takiej formie procedura ta została ukształtowana nowelą z dnia 19 lipca 2019 r. Do dnia 4 października 2019 r. ustawa dawała pokrzywdzonemu prawo wniesienia subsydiarnego aktu oskarżenia bezpośrednio po otrzymaniu zawiadomienia o ponownej decyzji o umorzeniu postępowania. Obecnie złożenie aktu oskarżenia uzależnione jest od wniesienia zażalenia do prokuratora nadrzędnego nad tym, który wydał ponowne postanowienie o umorzeniu. Dopiero w razie utrzymania w mocy takiego postanowienia pokrzywdzony, który dwukrotnie zaskarżył decyzje o umorzeniu, może wnieść akt oskarżenia, stając się oskarżycielem subsydiarnym. Rozwiązanie to funkcjonowało już, choć nie $\mathrm{w}$ identycznej formie, na gruncie K.p.k. do lipca 2007 r., kiedy mocą nowelizacji z dnia 29 marca 2007 r. ${ }^{13}$ wyeliminowano pośrednictwo prokuratora nadrzędnego w omawianej procedurze. Zmiany uzasadniano wówczas ogólną intencją ograniczenia prokuratorskiego nadzoru instancyjnego i przekazania dotychczasowych zadań procesowych prokuratora nadrzędnego do właściwości sądu (znowelizowany art. $465 \S 2$ K.p.k. $)^{14}$.

Prokuratorski nadzór instancyjny jest kwestią wyboru pomiędzy uproszczeniem i przyspieszeniem procedowania w tym zakresie a wzmocnieniem kontroli $\mathrm{w}$ ramach organów ścigania w celu zwiększenia prawdopodobieństwa wykrycia ewentualnych nieprawidłowości bez potrzeby ingerencji sądu. Ustawodawca nowelizując art. 330 § 2 K.p.k., opowiedział się raz jeszcze za drugim rozwiązaniem, przyjmując, że zaskarżenie ponownego postanowienia o umorzeniu do prokuratora nadrzędnego umożliwi usunięcie już na tym etapie „ewentualnych usterek tej decyzji, formalnych lub merytorycznych, ze szczególnym uwzględnieniem

12 Z rozpoznawanych przez sądy zażaleń ok. 25\% jest uwzględnianych (w 2016 r. - 24,1\%, w 2017 r. - 25,7\%, zaś w 2018 r. - 25,8\%). Dane na podstawie corocznych Sprawozdań Prokuratury Krajowej.

13 Ustawa z dnia 29 marca 2007 r. o zmianie ustawy o prokuraturze, ustawy - Kodeks postępowania karnego oraz niektórych innych ustaw, Dz. U. z 2007 r. Nr 64, poz. 432.

14 Uzasadnienie rządowego projektu ustawy o zmianie ustawy o prokuraturze... 
wykonania wytycznych sądu uchylającego poprzednio wydane postanowienie". Niewątpliwie zamierzeniem ustawodawcy było ograniczenie aktów oskarżenia kierowanych przez pokrzywdzonych ${ }^{15}$. Odnosząc się to takiego rozwiązania, podkreślić należy, że z jednej strony zwiększa ono kontrolę postanowień o umorzeniu $\mathrm{w}$ ramach prokuratury ${ }^{16}, \mathrm{z}$ drugiej natomiast powoduje wydłużenie tego postępowania incydentalnego, rozszerzając jednocześnie zakres obowiązków pokrzywdzonego, co z pewnością zniechęci przynajmniej część pokrzywdzonych do korzystania $\mathrm{z}$ drogi zażaleniowej ${ }^{17}$. Formalizm i wieloetapowość procedury prowadzącej do uzyskania statusu oskarżyciela subsydiarnego jest bowiem słusznie uważana za główną przyczynę sporadycznego korzystania z tej instytucji przez pokrzywdzonych ${ }^{18}$.

\section{Przymus adwokacko-radcowski}

Kolejna kwestia, na którą należy zwrócić uwagę, dotyczy subsydiarnego aktu oskarżenia. Ze względu na publicznoskargowy charakter

15 Por. uzasadnienie rządowego projektu ustawy o zmianie ustawy - Kodeks postępowania karnego oraz niektórych innych ustaw z dnia 21 lutego 2019 r., Druk nr 3251, http:/ / www.sejm.gov.pl/Sejm8.nsf/PrzebiegProc.xsp?nr=3251

16 Wskazuje się, że przyczyni się to do większej racjonalności i zasadności wnoszenia aktów oskarżenia przez pokrzywdzonego (A. Dziergawka, Subsydiarny akt oskarżenia w świetle nowelizacji dokonanej ustawa z dnia 19 lipca 2019 r., Prokuratura i Prawo 2020, nr 1, s. 159). Przed nowelizacją także D. Stachurski, Sądowa kontrola zaniechania ścigania - rzeczywiste czy pozorne wzmocnienie zasady legalizmu w procesie karnym?, Przegląd Sądowy 2012, nr 3, s. 108.

17 Zob. Ł. Chmielniak, M. Klonowski, A. Rychlewska-Hotel, Kodeks postępowania karnego. Komentarz praktyczny do nowelizacji 2019, red. J. Zagrodnik, Warszawa 2020 [wyd. el. LEX]. Tak również D. Drajewicz, w: Kodeks postępowania karnego, t. 1. Komentarz. Art. 1-424, red. D. Drajewicz, Warszawa 2020, s. 1583; Z. Brodzisz, w: Kodeks postępowania karnego. Komentarz, red. J. Skorupka, Warszawa 2020, s. 874-875; P. Misztal, Strony postępowania, w: MERITUM postępowanie karne, red. D. Świecki, Warszawa 2019, s. 285.

18 A. Gerecka-Żołyńska, N. Janowska, M. Ostrzycka, A. Woźniak, M. Zamroczyńska, Procesowa pozycja nieprokuratorskich organów oskarżenia publicznego w świetle zasady legalizmu, w: Zasada legalizmu w procesie karnym, t. 1, s. 57-58. O determinacji pokrzywdzonego m.in. A. Dziergawka, Subsydiarny akt..., s. 157. 
przestępstwa ma on znamiona skargi publicznej ${ }^{19}$, co powoduje wymóg sporządzenia i podpisania przez adwokata, radcę prawnego albo radcę Prokuratorii Generalnej. W tym zakresie trzeba odnieść się do zmian konstrukcji art. $55 \S 2$ K.p.k. W pierwotnym brzmieniu przepis ten wymagał sporządzenia i podpisania aktu oskarżenia przez „adwokata lub radcę prawnego", następnie nowela z dnia 27 września 2013 r. ${ }^{20}$ zmieniła to sformułowanie na „pełnomocnika”, zaś ustawa z dnia 19 lipca 2019 r. powróciła do sformułowania poprzedniego, dodając do adwokata i radcy prawnego radcę Prokuratorii Generalnej RP21.

Oceniając powyższe zmiany, należy zwrócić uwagę na kilka problemów. Przede wszystkim obowiązek sporządzenia i podpisania pisma przez osobę posiadającą uprawnienia radcowskie lub adwokackie nie jest tożsamy z obowiązkiem dokonania tych czynności przez pełnomocnika, którym może być adwokat lub radca prawny. Konieczność ustanowienia pełnomocnika, choćby tylko dla sporządzenia aktu oskarżenia, pociąga za sobą dalsze konsekwencje, istotne dla pokrzywdzonego. Przede wszystkim odbiera uprawnienia do dokonania tych czynności przez pokrzywdzonego będącego adwokatem lub radcą prawnym oraz nakłada na niego obowiązki związane ze sformalizowaniem relacji z adwokatem lub radcą prawnym poprzez konieczność udzielenia pełnomocnictwa. Niezwykle istotnym i problematycznym skutkiem takiego rozwiązania jest także możliwość odmiennego spojrzenia na zasadność oskarżenia' ${ }^{22}$. Niewątpliwie

19 Por. m.in.: T. Grzegorczyk, Kodeks postepowania karnego, t. 1. Komentarz do art. 1-467, Warszawa 2014, s. 86; J. Zagrodnik, Instytucja skargi subsydiarnej w procesie karnym, Warszawa 2005, s. 279; A. Cader, Oskarżyciel subsydiarny w sprawach o przestępstwa publicznoskargowe, w: Nowa kodyfikacja prawa karnego, t. 13, red. L. Bogunia, Wrocław 2003, s. 154. Nie jest to jednak stanowisko jednolite. Por. np.: R.A. Stefański, Z. Gostyński, w: Kodeks postępowania karnego. Komentarz, t. 1, red. J. Bratoszewski, L. Gardocki, Z. Gostyński, S.M. Przyjemski, R.A. Stefański, S. Zabłocki, s. 462-463; K. Dudka, Skarga subsydiarna oskarżyciela posiłkowego w procesie karnym, w: Wspótczesny polski proces karny. Księga ofiarowana Profesorowi Tadeuszowi Nowakowi, red. S. Stachowiak, Poznań 2002, s. 47.

20 Dz. U. z 2013 r. poz. 1247 z późn. zm.

${ }^{21}$ Por. słuszne wątpliwości co do takiego rozszerzenia: J. Kluza, Subsydiarny akt oskarżenia w perspektywie nowelizacji kodeksu postępowania karnego - ustawy z 19 lipca 2019 r., Studia Prawnicze i Administracyjne 2019, nr 28 (2), s. 18.

22 Szerzej S. Steinborn, Węzłowe problemy subsydiarnego oskarżenia positkowego, Prokuratura i Prawo 2001, nr 12, s. 72-75. Por. także S. Szołucha, w: Kodeks postepowania karnego. Komentarz, red. J. Skorupka, Warszawa 2020, s. 207; D. Świecki, Czynności procesowe obrońcy i petnomocnika w sprawach karnych, Warszawa 2018, s. 133. 
więc rozwiązanie to zwiększa formalizm, zniechęcający część pokrzywdzonych do realizacji uprawnień. $Z$ drugiej jednak strony pełnomocnik będący reprezentantem pokrzywdzonego ma przede wszystkim prawo bezpośredniego, osobistego dostępu do akt sprawy. Ponadto zapewnia spojrzenie osoby niezaangażowanej w sprawę, co zwiększa obiektywizm oceny sytuacji. Korzystanie z pomocy pełnomocnika daje też pokrzywdzonemu możliwość wnioskowania o ustanowienie go z urzędu ze względu na złą sytuację materialną.

Przegląd uzasadnień zmian w tym zakresie prowadzi natomiast do wniosku, że projektodawcy nie analizowali ich z perspektywy procesowej pokrzywdzonego. Wprowadzenie obowiązkowego korzystania $\mathrm{z}$ "pełnomocnika" uzasadniano potrzebą stylistycznego ujednolicenia tekstu ${ }^{23}$, co wskazuje, że zmiany te miały w założeniu jedynie charakter redakcyjny, z czym zgodzić się oczywiście nie można. Z kolei nowelizacja z 2019 r. powracająca do klasycznego przymusu adwokacko-radcowskiego była konsekwencją wyroku Trybunału Konstytucyjnego z dnia 21 czerwca 2016 r., w którym uznano za niezgodne z art. 45 ust. 1 Konstytucji RP rozwiązanie wyłączające możliwość sporządzenia i podpisania kasacji we własnej sprawie przez adwokata bądź radcę prawnego ${ }^{24}$. Wskazano, że takie rozwiązanie nie jest niezbędne dla realizacji celów przymusu adwokackiego, za który uznano odpowiednie pod względem merytorycznym i formalnym przygotowanie określonego pisma procesowego ${ }^{25}$.

23 Rządowy projekt ustawy o zmianie ustawy - Kodeks postępowania karnego, ustawy - Kodeks karny i niektórych innych ustaw z dnia 8 listopada 2012 r., Druk nr 870, http://www.sejm.gov.pl/Sejm7.nsf/PrzebiegProc.xsp?nr=870. Uzasadniano potrzebę zastąpienia w Kodeksie sformułowań „pełnomocnik będący adwokatem lub radcą prawnym” wyrażeniem "pełnomocnik". Projektodawca jako przykład wskazał art. 55 K.p.k., mimo że w jego brzmieniu nigdy nie było zapisu "pełnomocnik będący adwokatem lub radcą prawnym".

24 Podobnie postanowienie SN z dnia 3 lutego 2003 r., II KZ 61/02, LEX nr 77203. Analiza orzecznictwa prowadzi do wniosku, że pogląd taki jest sprzeczny z dominującą do tej pory linią orzeczniczą. Por. np. postanowienia SN: z dnia 23 listopada 2016 r., III KZ 76/16, LEX nr 2152399; z dnia 15 czerwca 2016 r., II KZ 16/16, LEX nr 2054092; z dnia 8 kwietnia 2016 r., II KZ 6/16, LEX nr 2016027; z dnia 15 grudnia 2010 r., IV KZ 73/10, LEX nr 843931; z dnia 19 marca 2009 r., III KZ 15/09, LEX nr 511558; z dnia 20 lipca 2006 r., V KZ 27/06, LEX nr 323213.

25 Według niektórych poglądów w przymusie adwokacko-radcowskim „ważny jest także odpowiedni dystans do sprawy”, , ,odsunięcie od siebie emocji, które mogą utrudniać prawidłowy osąd sprawy". Zob. M. Fingas, Postępowanie karne - uprawnienie do sporzadzenia 
Oceniając zmianę dokonaną w 2019 r. w art. 55 § 2 K.p.k., niewątpliwie należy stwierdzić, że jest ona korzystna z punktu widzenia pokrzywdzonego i zasługuje na aprobatę, zwalnia go bowiem z konieczności wyznaczania pełnomocnika, dając przy tym samodzielne uprawnienia tym pokrzywdzonym, którzy są adwokatami lub radcami prawnymi. Trzeba także podkreślić, że obecna konstrukcja nie zamyka pokrzywdzonemu drogi do korzystania z pomocy pełnomocnika w zakresie sporządzenia skargi, może on bowiem, jako strona procesowa, ustanowić pełnomocnika, a także wnioskować o pełnomocnika z urzędu ze względu na złą sytuację materialną.

\section{Uprawnienia pokrzywdzonych, którzy nie wnieśli subsydiarnego aktu oskarżenia}

Ustawodawca przyznał pokrzywdzonym, którzy nie wnieśli subsydiarnego aktu oskarżenia, prawo przyłączenia się do postępowania poprzez złożenie oświadczenia do czasu rozpoczęcia przewodu sądowego na rozprawie głównej. Każdy pokrzywdzony danym czynem może w takiej sytuacji przystąpić do postępowania, uzyskując uprawnienia oskarżyciela posiłkowego ubocznego. Nowelą z dnia 19 lipca 2019 r. sąd został przy tym zobowiązany do zawiadomienia o wniesieniu aktu oskarżenia innych znanych pokrzywdzonych. Zmianę tę należy uznać za logiczne uzupełnienie regulacji zawartej w art. $55 \S 2$ K.p.k., ponieważ „urealnia prawo innych pokrzywdzonych tym samym czynem do przyłączenia się na podstawie art. $55 \S 3$ do postępowania zainaugurowanego $\mathrm{w}$ sprawie publicznoskargowej na podstawie subsydiarnego aktu oskarżenia" ${ }^{26}$.

kasacji we wtasnej sprawie przez adwokata. Glosa do wyroku TK z dnia 21 czerwca 2016 r., SK 2/15, OSP 2017, z. 10, s. 95-101. Za dopuszczalnością samodzielnego wniesienia aktu przez adwokata opowiada się m.in.: D. Świecki, Czynności..., s. 131-132; A. Sikorski, Przymus adwokacko-radcowski w postępowaniu karnym, Nowa Kodyfikacja Prawa Karnego 2016, nr 41, s. 93-113; L.K. Paprzycki, Prawa i obowiazki pokrzywdzonego w postepowaniu przed sqdem karnym pierwszej instancji - zarys problematyki, Palestra 2000, nr 2-3, s. 32; K. Boratyńska, w: Kodeks postepowania karnego. Komentarz, red. A. Sakowicz, Warszawa 2015, s. 180; P. Hofmański, E. Sadzik, K. Zgryzek, Kodeks postępowania karnego, t. 1. Komentarz do artykutów 1-296, Warszawa 2011, s. 413; P. Misztal, Strony postępowania, s. 285.

26 Ł. Chmielniak, M. Klonowski, A. Rychlewska-Hotel, Kodeks... (komentarz do art. 55). 
Z pewnością przyznanie prawa pokrzywdzonym do przyłączenia się do oskarżenia subsydiarnego jest rozwiązaniem o znaczeniu gwarancyjnym, nie pozbawia bowiem innych pokrzywdzonych prawa do udziału w postępowaniu ze względu na stan zawisłości spawy wywołany wniesieniem aktu oskarżenia przez innego pokrzywdzonego. $Z$ drugiej jednak strony obecna regulacja może budzić pewne zastrzeżenia.

Przede wszystkim należy zauważyć, że ustawa nie uzależnia prawa do przyłączenia się do oskarżenia subsydiarnego od wyczerpania przez konkretnego pokrzywdzonego drogi zażaleniowej określonej w art. 330 i 55 K.p.k. Oznacza to, że każdy pokrzywdzony, niezależnie od zainteresowania sprawą po umorzeniu postępowania przygotowawczego, może ostatecznie uzyskać uprawnienia strony na etapie jurysdykcyjnym. O ile prawo takie nie budzi wątpliwości w odniesieniu do tych pokrzywdzonych, którzy wyczerpali drogę zażaleniową, ale nie mogą wnieść własnego aktu oskarżenia z uwagi na stan zawisłości sprawy spowodowany wcześniejszym złożeniem skargi przez innego pokrzywdzonego, o tyle w stosunku do tych, którzy nie kwestionowali decyzji o umorzeniu, mogą pojawić się istotne wątpliwości. W doktrynie i orzecznictwie słusznie podkreśla się, że wnoszący skargę nie może wyjść poza granice zarzutu ${ }^{27}$. Konkretny pokrzywdzony uzyskuje prawo wniesienia subsydiarnego aktu oskarżenia tylko w granicach, w jakich w postępowaniu karnym chronione są jego indywidualne interesy, a więc dana osoba może wystąpić $z$ oskarżeniem wyłącznie w zakresie czynów bezpośrednio naruszających lub zagrażających dobrom prawnym, które jej przysługują. Wyklucza to objęcie aktem części tych zachowań oskarżonego, które nie dotyczą bezpośrednio dóbr prawnych danego pokrzywdzonego ${ }^{28}$. Zakres uprawnienia do wniesienia aktu oskarżenia przez pokrzywdzonego uzależniony jest więc od bezpośredniego naruszenia lub zagrożenia indywidualnych dóbr

27 Zob. np.: postanowienie SN z dnia 9 lutego 2017 r., IV KK 299/16, LEX nr 2255432; postanowienie SA w Katowicach z dnia 17 marca 2010 r., II AKz 107/10, https://www.saos.org.pl/judgments/146703; postanowienie SA we Wrocławiu z dnia 31 maja 2016 r., II AKz 145/16, LEX nr 2052579.

28 Por. m.in.: wyrok SN z dnia 7 kwietnia 2016 r., IV KK 363/15, LEX nr 2038978; postanowienie SA w Warszawie z dnia 13 grudnia 2012 r., II AKz 715/12, LEX nr 1246951; postanowienie SA w Katowicach z dnia 5 grudnia 2012 r., II AKz 692/12, LEX nr 1298152. 
konkretnej osoby ${ }^{29}$. Nie można jednocześnie wykluczyć, że w odniesieniu do poszczególnych pokrzywdzonych umorzenie postępowania było uwarunkowane innymi przyczynami, zaś skuteczne zaskarżenie zaniechania ścigania $w$ odniesieniu do jednej $z$ osób nie oznacza automatycznie zasadności jego kwestionowania w stosunku do pozostałych. Jeśli postanowienie o umorzeniu nie zostało zaskarżone $\mathrm{w}$ odniesieniu do konkretnego pokrzywdzonego, uzyskuje cechę prawomocności, co wydaje się niezwykle istotne dla oceny dopuszczalności przyłączenia się takiego pokrzywdzonego do postępowania, które de facto $\mathrm{w}$ odniesieniu do niego zostało prawomocnie zakończone ${ }^{30}$.

Stąd też racjonalne wydaje się uzależnienie możliwości przyłączenia się do oskarżenia subsydiarnego od uzyskania "prawa do oskarżenia” (w sensie przedmiotowym, a nie formalnym), będącego następstwem wyczerpania drogi zażaleniowej. Prawo to jest bowiem konsekwencją zakwestionowania decyzji o umorzeniu postępowania przygotowawczego w zakresie czynu naruszającego dobra konkretnego pokrzywdzonego. Podważenie zasadności takiej decyzji następuje najpierw przez samego pokrzywdzonego (poprzez wniesienie zażalenia na postanowienie o umorzeniu), a następnie przez sąd (poprzez postanowienie o uchyleniu decyzji i przekazaniu sprawy prokuratorowi). Ustawowym wymogiem uzyskania prawa do skargi jest także ponowna weryfikacja decyzji o umorzeniu przez prokuratora (poprzez wykonanie dodatkowych czynności i wyjaśnienie okoliczności) i prokuratora nadrzędnego (utrzymującego $\mathrm{w}$ mocy ponowne postanowienie o umorzeniu). Taki proces badania decyzji o umorzeniu postępowania przygotowawczego w odniesieniu do każdego pokrzywdzonego dawałby każdemu z nich prawo do uzyskania statusu strony procesowej.

Argumentem wspierającym przedstawione stanowisko jest także, wbrew pozorom, nierówne traktowanie pokrzywdzonych. Jak już podkreślono, spełnienie warunków niezbędnych do uzyskania uprawnienia do wejścia w rolę strony procesowej jest trudne i z różnych względów wymagające. Wieloetapowa procedura zmierza nie tylko do wyeliminowania

29 Por. także J. Kluza, Subsydiarny..., s. 17; K. Eichstaedt, w: Kodeks postępowania karnego. Komentarz, t. 1. Art. 1-424, red. D. Świecki, Warszawa 2017, s. 342; D. Świecki, Czynności..., s. 127; S. Steinborn, Węzłowe problemy..., s. 66.

30 Por także uwagi S. Łagodzińskiego, Pokrzywdzony jako oskarżyciel positkowy w sprawach publicznoskargowych, Prawo w Działaniu 2008, t. 3, s. 152-186. 
niezasadnych oskarżeń zastępujących oskarżenie publiczne, lecz także niewątpliwie zniechęca wielu pokrzywdzonych. Patrząc na treść art. 55 $\S 3$ K.p.k. z tej perspektywy, może wydawać się więc niesłuszne jednakowe traktowanie każdego pokrzywdzonego. Ustawa zrównuje bowiem prawa tego pokrzywdzonego, który wyczerpał drogę zażaleniową i wniósł oskarżenie oraz tego (tych), którzy nie podejmowali żadnych działań w zakresie kwestionowania umorzenia.

Oceniając prawo przyłączenia się pokrzywdzonych do oskarżenia subsydiarnego trzeba zauważyć, że analogiczne prawo przewidziane jest zarówno w odniesieniu do skargi oskarżyciela publicznego, jak i skargi prywatnej. W każdym zatem przypadku pokrzywdzony czynem wskazanym w akcie oskarżenia (publicznym, posiłkowym, prywatnym) może przyłączyć się do postępowania wszczętego skargą wniesioną przez inny podmiot. Ustawodawca zrównał więc uprawnienia pokrzywdzonych w tym zakresie. Wydaje się jednak, że sytuacja w obrębie oskarżenia subsydiarnego jest odmienna i powinna być inaczej traktowana. Zasadnicza skarga publiczna (prokuratorski akt oskarżenia) wnoszona jest w interesie publicznym, obejmującym także interes każdego pokrzywdzonego, zaś oskarżyciel publiczny zobowiązany jest do wypełniania swojej funkcji jako reprezentant państwa, działający nie we własnym, ale w publicznym interesie. Prawo każdego pokrzywdzonego do przyłączenia się do postępowania zainicjowanego publicznym aktem oskarżenia nie budzi zatem wątpliwości, zarówno z punktu widzenia równego traktowania podmiotów, jak i zakresu skargi, do której się oni przyłączają. Skarga prywatna z kolei wnoszona jest przez pokrzywdzonego bez przeprowadzenia postępowania przygotowawczego. Jest to więc pierwsza czynność podejmowana przez uprawniony podmiot, która inicjuje proces karny i powoduje zawisłość sprawy. Trudno byłoby wyobrazić sobie inne rozwiązanie niż możliwość przyłączenia się do postępowania innych pokrzywdzonych, którzy kolejnych aktów wnieść nie mogą.

Powyższe rozważania prowadzą do wniosku, że warte namysłu byłoby wprowadzenie regulacji, które uzależniałyby nabycie statusu strony poprzez przyłączenie się do oskarżenia subsydiarnego od wyczerpania drogi zażaleniowej. Przemawiają za tym zarówno argumenty odnoszące się do zakresu skargi subsydiarnej i reprezentowanego w niej interesu, możliwości kwestionowania zasadności umorzenia postępowania przez każdego z pokrzywdzonych, jak i racje wynikające z zakresu obowiązków związanych z wniesieniem skargi. Takie rozwiązanie może oczywiście 
budzić wątpliwości z uwagi na dalsze, i tak już znaczne ograniczenie praw pokrzywdzonego $\mathrm{w}$ tej sferze. Nie można zaprzeczyć, że wieloetapowa procedura prowadząca do uzyskania praw oskarżycielskich i przymus adwokacko-radcowski stanowią znaczne utrudnienia dla pokrzywdzonego, niemniej trzeba podkreślić, że regulacje te dotyczą trybu publicznoskargowego, który w założeniu pozostawia oskarżycielowi publicznemu decyzję odnośnie do wniesienia oskarżenia. Propozycja ta otwiera w tym zakresie pole do dalszej dyskusji.

\section{Relacja pomiędzy oskarżycielem subsydiarnym a prokuratorem}

Dwukrotna decyzja o umorzeniu postępowania przygotowawczego wyraża brak woli wniesienia oskarżenia do sądu i tym samym zaniechanie przekształcenia funkcji ścigania w funkcję oskarżenia. Mimo to ustawodawca przyznał prokuratorowi prawo przyłączenia się do sprawy wszczętej na podstawie posiłkowego aktu oskarżenia. Takie rozwiązanie podyktowane jest uznaniem nadrzędności prokuratora jako głównego oskarżyciela publicznego nad innymi podmiotami w zakresie realizacji funkcji oskarżenia w postępowaniu o przestępstwa publicznoskargowe.

Do dnia wejścia w życie ustawy z dnia 11 marca 2016 r. ${ }^{31}$ art. 55 $\S 4$ K.p.k. przewidywał prawo "udziału” w tej sprawie prokuratora, nie rozstrzygając wprost ani pozycji zajmowanej przez niego w tym przypadku, ani też charakteru pełnionej funkcji. W literaturze prezentowane były różne poglądy co do stanowiska i roli prokuratora w takiej sytuacji ${ }^{32}$. Wątpliwości te zostały rozwiane wspomnianą nowelą ${ }^{33}$. W odniesieniu do sposobu ingerencji prokuratora przepisy stwierdzają, że prokurator może

31 Ustawa z dnia 11 marca 2016 r. o zmianie ustawy - Kodeks postępowania karnego oraz niektórych innych ustaw, Dz. U. z 2016 r. poz. 437 z późn. zm., weszła w życie w dniu 15 kwietnia 2016 r.

32 Część przedstawicieli doktryny traktowała go jako oskarżyciela głównego, inni natomiast postrzegali go przede wszystkim jako rzecznika interesu publicznego. Zestawienia prezentowanych w tym względzie poglądów dokonał R.A. Stefański, Przegląd uchwał Izby Karnej Sądu Najwyższego w zakresie postępowania karnego za 2013 r., Ius Novum 2014, t. 8, nr 3, s. 104.

$33 \mathrm{O}$ uzasadnieniu opinii prezentowanych podczas prac parlamentarnych zob. M. Goss-Przygucka, Udziat prokuratora w postępowaniu wszczętym przez oskarżyciela 
wstąpić do toczącego się postępowania, przy czym decyzja ta nie jest ograniczona żadnym terminem. Wstąpienie do postępowania oznacza, że mimo iż prokurator nie wniósł oskarżenia, to jednak chce je popierać jako oskarżyciel publiczny. Na marginesie warto zauważyć nieco niefortunną konstrukcję art. 55 § 4 K.p.k., który stwierdza, że wstąpienie prokuratora do postępowania oznacza, że toczy się ono wówczas z oskarżenia publicznego. Jeśli ustawodawca chciał $\mathrm{w}$ ten sposób wyrazić, że postępowanie prowadzone jest $\mathrm{w}$ trybie publicznoskargowym, to powyższa konstrukcja sugeruje, że postępowanie prowadzone na podstawie subsydiarnego aktu oskarżenia nie jest postępowaniem publicznoskargowym, co prawdą oczywiście nie jest. Jeśliby natomiast sformułowanie użyte w przepisie odczytywać dosłownie, to także trudno się z nim zgodzić, bowiem podstawą prowadzenia postępowania jest nadal oskarżenie subsydiarne. Przyłączenie się prokuratora nie zmienia przecież podstawy procedowania, prokurator nie wnosi bowiem własnego oskarżenia.

Z uwagi na konieczność zagwarantowania ochrony interesów pokrzywdzonego, który samodzielnie wniósł oskarżenie zamiast prokuratora, art. 55 § 4 K.p.k. wyraźnie stanowi, że pojawienie się oskarżyciela publicznego nie pozbawia go dotychczasowych uprawnień strony, zmieniając jedynie charakter jego udziału z oskarżyciela samodzielnie popierającego wniesiony przez siebie akt oskarżenia na oskarżyciela, który działa obok oskarżyciela publicznego, na zasadach właściwych dla postępowania $\mathrm{w}$ trybie publicznoskargowym. Taką samą pozycję zajmują pozostali pokrzywdzeni, którzy poprzez oświadczenie przyłączyli się do oskarżenia subsydiarnego. Wyraźne uregulowanie charakteru ingerencji prokuratora oraz zajmowanej pozycji należy uznać za słuszne rozwiązanie, określające sytuację procesową pokrzywdzonych w sposób niebudzący wątpliwości.

Skoro prokurator wchodzi w rolę oskarżyciela publicznego, jego udział w postępowaniu podporządkowany jest zasadom działania takiego oskarżyciela. Wyrazem tych reguł jest prawo cofnięcia aktu oskarżenia. Brzmienie art. $14 \S 2$ K.p.k. nie daje bowiem podstaw do ograniczenia praw prokuratora w tym zakresie w sytuacji, w której wstąpił on do postępowania prowadzonego na podstawie skargi subsydiarnej. Przepis ten wskazuje bowiem uprawnienie oskarżyciela publicznego niezależnie od 
tego, czy stał się nim poprzez wniesienie oskarżenia, czy poprzez wstąpienie do postępowania zainicjowanego oskarżeniem pokrzywdzonego. Ponadto regulacja ta nie uzależnia prawa cofnięcia skargi przez oskarżyciela publicznego od jej rodzaju. Nie ogranicza zatem tego uprawnienia do aktu oskarżenia wniesionego przez oskarżyciela publicznego, który chce go cofnąć, nie posługuje się także dookreśleniem „publicznego" aktu oskarżenia, który można cofnąć. Pomimo więc odstąpienia od wniesienia oskarżenia, oskarżyciel publiczny może cofnąć subsydiarny akt oskarżenia, do którego się przyłączył. Rozwiązanie takie jest słusznie krytykowane w doktrynie, bowiem „oskarżyciel publiczny staje się zasadniczo dysponentem skargi karnej oskarżyciela posiłkowego" $\mathrm{i}$ „,nie ma racjonalnego uzasadnienia takie przyznanie oskarżycielowi publicznemu uprawnienia do pozbawienia znaczenia procesowego czynności dokonanej uprzednio przez oskarżyciela posiłkowego polegającej na wniesieniu subsydiarnego aktu oskarżenia" 34 .

Przy obecnym rozwiązaniu istnieje $\mathrm{w}$ związku $\mathrm{z}$ powyższym niezaprzeczalna potrzeba zapewnienia ochrony interesów pokrzywdzonego, która musi być jeszcze dobitniej podkreślona w aktualnym stanie prawnym, w którym cofnięcie aktu oskarżenia zastąpiło dotychczasowe niewiążące sądu odstąpienie od oskarżenia. Ustawą z dnia 11 marca 2016 r. uzupełniono treść art. 55 § 4 K.p.k. o zapis uzależniający cofnięcie subsydiarnego aktu oskarżenia przez oskarżyciela publicznego od zgody tego pokrzywdzonego, który go wniósł. Rozwiązanie to uznać należy za niezbędne dla zapewnienia właściwej ochrony praw pokrzywdzonego w omawianej sytuacji. Co więcej, zrównanie praw wszystkich pokrzywdzonych, którzy przed wstąpieniem prokuratora uzyskali status strony procesowej, powoduje, że również w zakresie wymogu uzyskania zgody na cofnięcie aktu oskarżenia konieczne jest zachowanie równości. Dlatego też z aprobatą należy odnieść się do ostatnich zmian art. 55 K.p.k., na mocy których w razie przyłączenia się innego pokrzywdzonego (albo innych pokrzywdzonych) do postępowania prowadzonego na podstawie subsydiarnego aktu oskarżenia cofnięcie aktu oskarżenia przez oskarżyciela publicznego wymaga zgody wszystkich pokrzywdzonych będących oskarżycielami posiłkowymi. Brak zgody choćby jednego z nich, niezależnie od tego, czy wniósł on

34 J. Zagrodnik, Udziat prokuratora w postępowaniu sądowym wszczętym przez oskarżyciela positkowego subsydiarnego, Prokuratura i Prawo 2017, nr 2, s. 13-15. 
oskarżenie, czy tylko przyłączył się do sprawy, powoduje nieskuteczność oświadczenia o cofnięciu aktu oskarżenia.

\section{Odstąpienie oskarżyciela subsydiarnego od oskarżenia}

Subsydiarny akt oskarżenia jest oświadczeniem woli podmiotu, który go wnosi. Taki sam charakter ma oświadczenie złożone przez pokrzywdzonego, który przyłączył się do postępowania. Każdy z nich ma prawo odstąpić od wniesionego (lub popieranego) przez siebie oskarżenia. Z uwagi na fakt, iż oskarżyciel subsydiarny występuje w postępowaniu zamiast oskarżyciela publicznego, jego odstąpienie od oskarżenia powoduje brak podmiotu popierającego skargę, co należy rozpatrywać w kategoriach przeszkody do kontynuowania postępowania. Należy jednak podkreślić, że zrównanie uprawnień oskarżyciela subsydiarnego i pokrzywdzonych, którzy przyłączyli się do postępowania, oznacza, że brak podmiotu popierającego skargę wystąpi dopiero wtedy, gdy wszyscy pokrzywdzeni będący oskarżycielami popierającymi subsydiarny akt oskarżenia złożą oświadczenie o odstąpieniu od oskarżenia ${ }^{35}$. Słusznie wskazuje się, że przyjęcie innej koncepcji jest nie do pogodzenia z konstytucyjnym prawem do sądu ${ }^{36}$.

35 Zob. m.in.: J. Kluza, Subsydiarny..., s. 18; K. Dudka, Ograniczenie liczby oskarżycieli positkowych w polskim procesie karnym, Prokuratura i Prawo 2004, nr 7-8, s. 91; R. Troll, Charakter procesowy pokrzywdzonego przyłaczajacego się do postępowania na podstawie art. $55 \S 3$ k.p.k., Przegląd Sądowy 2003, nr 5, s. 112; S. Steinborn, Węztowe problemy ..., s. 86; K. Eichstaedt, w: Kodeks postępowania karnego. Komentarz, t. 1. Art. 1-424, s. 349; K. Gajowniczek-Pruszyńska, w: K. Gajowniczek-Pruszyńska, P. Karlik, Kodeks postepowania karnego. Komentarz do ustawy z 19.7.2019 r., Warszawa 2020, s. 30. W doktrynie sformułowano także opinie odmienne, wskazujące, że pokrzywdzony, który przyłączył się do postępowania, nie może "objąćc oskarżenia w razie odstąpienia oskarżyciela subsydiarnego od oskarżenia. Taki pokrzywdzony, w sytuacji nieprzyłączenia się wówczas oskarżyciela publicznego, traci swoje prawa i postępowanie jest umorzone. Zob. T. Grzegorczyk, Kodeks postępowania karnego, t. 1, s. 288; K. Papke-Olszauskas, Oskarżyciel positkowy w polskim procesie karnym - wybrane zagadnienia, Palestra 2000, nr 1, s. 50-51; W. Grzeszczyk, Kodeks postępowania karego. Komentarz, Warszawa 2014, s. 108; P. Hofmański, E. Sadzik, K. Zgryzek, Kodeks..., s. 423; E. Kruk, Skarga..., s. 311.

36 A. Dziergawka, Subsydiarny akt oskarżenia jako realizacja prawa do sadu, w: Oblicza Temidy. Wybrane problemy prawa i procesu karnego, red. I. Zgoliński, Bydgoszcz 2012, s. 105. 
Nowela z dnia 19 lipca 2019 r. wprowadziła przy tym domniemanie prawne niewzruszalne (praesumptio iuris ac de iure), zgodnie z którym niestawiennictwo oskarżyciela posiłkowego i jego pełnomocnika na rozprawie głównej bez usprawiedliwienia uważa się za odstąpienie od oskarżenia. Podstawa domniemania wymaga przy tym stwierdzenia nieusprawiedliwionego niestawiennictwa zarówno oskarżyciela, jak i jego pełnomocnika.

Wskazuje się, że wprowadzenie konkludentnego odstąpienia od oskarżenia subsydiarnego umożliwia zaniechanie prowadzenia postępowania wbrew woli pokrzywdzonego, który nie jest zainteresowany sprawą lub zmienił swoje stanowisko ${ }^{37}$. W uzasadnieniu tej zmiany projektodawca argumentował natomiast, że „nie ma dostatecznie ważkiego powodu, aby sąd wyręczał oskarżyciela w postępowaniu wszczętym z jego inicjatywy i kontynuował proces w sytuacji, gdy oskarżyciel takiego zainteresowania nie wykazuje" ${ }^{38}$. Ustawodawca zdecydował się więc na wprowadzenie dorozumianej formy odstąpienia od oskarżenia, wzorowanej na rozwiązaniu występującym $w$ postępowaniu prywatnoskargowym (art. 496 § 3, art. 491 § 1 K.p.k.). Z jednej strony wskazać można na argumenty za racjonalnością takiego rozwiązania z uwagi na podobieństwo między oskarżycielem subsydiarnym i prywatnym w zakresie podmiotowym (w obie role wciela się pokrzywdzony przestępstwem) oraz przy uwzględnieniu faktu, iż w obu wypadkach to właśnie inicjatywa pokrzywdzonego determinuje prowadzenie postępowania sądowego, a ciężar obalenia domniemania niewinności niewątpliwie wymaga stawiennictwa i aktywności na rozprawie ${ }^{39}$. Z drugiej strony należy podkreślić, że sytuacja procesowa oskarżyciela subsydiarnego jest jednak odmienna. Jest to bowiem podmiot, który występuje w postępowaniu o przestępstwo publicznoskargowe, zastępując oskarżyciela publicznego. Trzeba przy tym zauważyć, że w sprawach o przestępstwo ścigane z oskarżenia publicznego udział oskarżyciela publicznego w rozprawie nie zawsze jest obowiązkowy (art. 46 K.p.k.). Wówczas niestawiennictwo oskarżyciela publicznego nie tamuje rozprawy, chyba że przewodniczący lub sąd uznają jego obecność za obowiązkową.

37 Tamże, s. 163.

38 Uzasadnienie noweli z dnia 19 kwietnia 2019 r. Jednoznacznie pozytywnie o tej zmianie K. Wytrykowski, w: Kodeks postępowania karnego, t. 1, red. D. Drajewicz, s. 272.

39 Por. także J. Kluza, Subsydiarny..., s. 18. 
Zestawienie treści art. 46 K.p.k. i 57 § 1a K.p.k. prowadzi więc do wniosku o różnym traktowaniu oskarżycieli występujących w trybie publicznoskargowym w zakresie obowiązku ich udziału w postępowaniu i skutków ich niestawiennictwa. Pokrzywdzony występujący w charakterze oskarżyciela subsydiarnego jest traktowany ze znacznie większym rygoryzmem $\mathrm{w}$ tym zakresie. Nie wydaje się, by było to rozwiązanie słuszne.

Na gruncie przepisów dotyczących odstąpienia oskarżyciela subsydiarnego (i innych pokrzywdzonych, którzy przyłączyli się do postępowania) od oskarżenia zauważyć należy kolejne rozwiązanie, które świadczy o tym, że samodzielność oskarżenia pokrzywdzonego nie powoduje modyfikacji trybu ścigania. Nadal toczy się ono w trybie publicznoskargowym, którego jedną z najistotniejszych cech jest nadrzędna rola prokuratora jako głównego i zasadniczego oskarżyciela. Wyrazem pozycji prokuratora i specyfiki publicznoskargowego trybu ścigania przestępstw jest uzależnienie umorzenia postępowania z powodu odstąpienia oskarżyciela subsydiarnego (i innych popierających oskarżenie) od oskarżenia od decyzji prokuratora co do przystąpienia do subsydiarnego aktu oskarżenia. Sąd zobowiązany jest bowiem do zawiadomienia prokuratora o odstąpieniu (ostatniego) oskarżyciela popierającego posiłkowy akt oskarżenia, pozostawiając w jego ręku ostateczną decyzję co do zasadności popierania takiej skargi. Dopiero nieprzystąpienie prokuratora do oskarżenia w ciągu 14 dni od doręczenia mu powyższego zawiadomienia obliguje sąd do umorzenia postępowania z uwagi na brak skargi uprawnionego oskarżyciela (art. 17 $\S 1$ pkt 9 K.p.k.).

\section{Zakończenie}

Instytucja oskarżenia subsydiarnego $\mathrm{w}$ połączeniu $\mathrm{z}$ sądową kontrolą zaniechania ścigania stanowi z pewnością jedną z najważniejszych gwarancji przestrzegania zasady legalizmu. Z punktu widzenia celów postępowania karnego określonych w art. $2 \S 1$ pkt 3 K.p.k. trzeba ją uznać za istotny składnik systemu ochrony praw pokrzywdzonego w procesie. Mimo iż uprawnienie do inicjowania postępowania sądowego w sprawach o przestępstwa publicznoskargowe nie jest powszechnie 
wykorzystywanym narzędziem walki o swój interes przez pokrzywdzonych $^{40}$, nie ulega wątpliwości, że oskarżenie subsydiarne jest konstrukcją potrzebną. Obawy przed nadużywaniem tej instytucji z pewnością są minimalizowane przez wieloetapową, skomplikowaną procedurę uzyskiwania statusu oskarżyciela subsydiarnego, przymus adwokacko-radcowski przy sporządzeniu posiłkowego aktu oskarżenia czy obowiązek ponoszenia kosztów procesu w razie uniewinnienia lub umorzenia postępowania. Wydaje się, że w wielu przypadkach zniechęca to pokrzywdzonych do podejmowania walki o własny interes. Ponowne wprowadzenie kontroli prokuratora nadrzędnego w procedurze prowadzącej do wniesienia oskarżenia subsydiarnego z pewnością tę niechęć jeszcze pogłębi. Z drugiej strony ustawodawca daje prawo uzyskania statusu strony pokrzywdzonemu, który formalnie nie kwestionował zasadności umorzenia postępowania, dzięki możliwości przyłączenia się do procesu wszczętego na podstawie aktu oskarżenia wniesionego przez innego pokrzywdzonego. Oceniając całokształt regulacji dotyczących oskarżyciela subsydiarnego, można dojść do wniosku, że z jednej strony, z uwagi na wyraźne brzmienie art. $2 \S 1$ pkt 3 K.p.k., ustawodawca zobowiązany do ochrony interesów pokrzywdzonego utrzymuje prawo oskarżania w trybie publicznoskargowym zamiast oskarżyciela publicznego. Z drugiej zaś wprowadza takie obostrzenia (dotyczące procedury, profesjonalnego pośrednictwa, kosztów), które w bardzo istotny sposób zniechęcają pokrzywdzonych. Taka intencja wybrzmiewa zresztą z uzasadnień wprowadzanych zmian. Wydaje się, że nie jest to dobre podejście. Należy się oczywiście zgodzić ze stanowiskiem, że warunki uzyskania prawa do oskarżania zamiast oskarżyciela publicznego powinny być tak ukształtowane, aby zminimalizować niebezpieczeństwo bezzasadnych oskarżeń. Niemniej winny one gwarantować realne, dostępne prawo do inicjowania

40 W latach 2002-2010 systematycznie wzrastała liczba osądzeń na podstawie subsydiarnego aktu oskarżenia (od 89 w 2002 r. do blisko 1000 w roku 2010; po noweli w 2007 r. liczba subsydiarnych aktów oskarżenia gwałtownie wzrosła do 652 w 2008 r. i do 1866 w 2014 r.), przy czym istotne jest także to, że w ponad 15\% takich spraw nastąpiło przypisanie sprawstwa i winy oskarżonemu w wyroku skazującym albo warunkowo umarzającym postępowanie. Por. G. Artymiak, Gwarancje realizacji przez pokrzywdzonego prawa do sadu w trybie skargi subsydiarnej - analiza praktyki $i$ uwagi de lege ferenda, w: Z problematyki funkcji..., s. 57-58; S. Waltoś, P. Hofmański, Proces karny. Zarys systemu, Warszawa 2018, s. 195. 
procesu sądowego tam, gdzie oskarżyciel publiczny, wbrew zasadzie legalizmu, zaniechał wykonywania funkcji ścigania i oskarżania.

\section{Bibliografia (wybór)}

Artymiak G., Gwarancje realizacji przez pokrzywdzonego prawa do sadu w trybie skargi subsydiarnej - analiza praktyki i uwagi de lege ferenda, w: Z problematyki funkcji procesu karnego, red. T. Grzegorczyk, J. Izydorczyk, R. Olszewski, Warszawa 2013.

Boratyńska K., w: Kodeks postępowania karnego. Komentarz, red. A. Sakowicz, Warszawa 2015.

Brodzisz Z., w: Kodeks postępowania karnego. Komentarz, red. J. Skorupka, Warszawa 2020.

Cader A., Oskarżyciel subsydiarny w sprawach o przestępstwa publicznoskargowe, w: Nowa kodyfikacja prawa karnego, t. 13, red. L. Bogunia, Wrocław 2003.

Chmielniak Ł., Klonowski M., Rychlewska-Hotel A., Kodeks postępowania karnego. Komentarz praktyczny do nowelizacji 2019, red. J. Zagrodnik, Warszawa 2020 [wyd. el. LEX].

Drajewicz D., w: Kodeks postępowania karnego, t.1. Komentarz. Art.1-424, red. D. Drajewicz, Warszawa 2020.

Dudka K., Ograniczenie liczby oskarżycieli positkowych w polskim procesie karnym, Prokuratura i Prawo 2004, nr 7-8.

Dudka K., Skarga subsydiarna oskarżyciela posiłkowego w procesie karnym, w: Wspótczesny polski proces karny. Ksiega ofiarowana Profesorowi Tadeuszowi Nowakowi, red. S. Stachowiak, Poznań 2002.

Dziergawka A., Subsydiarny akt oskarżenia jako realizacja prawa do sadu, w: Oblicza Temidy. Wybrane problemy prawa i procesu karnego, red. I. Zgoliński, Bydgoszcz 2012.

Dziergawka A., Subsydiarny akt oskarżenia w świetle nowelizacji dokonanej ustawa $z$ dnia 19 lipca 2019 r., Prokuratura i Prawo 2020, nr 1.

Eichstaedt K., w: Kodeks postępowania karnego. Komentarz, t. 1. Art. 1-424, red. D. Świecki, Warszawa 2017.

Fingas M., Postępowanie karne - uprawnienie do sporzadzenia kasacji we własnej sprawie przez adwokata. Glosa do wyroku TK z dnia 21 czerwca 2016 r., SK 2/15, OSP 2017, z. 10.

Gajowniczek-Pruszyńska K., w: K. Gajowniczek-Pruszyńska, P. Karlik, Kodeks postepowania karnego. Komentarz do ustawy z 19.7.2019 r., Warszawa 2020. 
Gerecka-Żołyńska A., Janowska N., Ostrzycka M., Woźniak A., Zamroczyńska M., Procesowa pozycja nieprokuratorskich organów oskarżenia publicznego w świetle zasady legalizmu, w: Zasada legalizmu w procesie karnym, t. 1, red. B. Dudzik, J. Kosowski, I. Nowikowski, Lublin 2015.

Goss-Przygucka M., Udział prokuratora w postępowaniu wszczętym przez oskarżyciela subsydiarnego po nowelizacji kodeksu postępowania karnego z 15.04.2016 r., Państwo i Prawo 2019, nr 4.

Grajewski J., Sadowa ingerencja w postępowanie przygotowawcze, w: Nowa kodyfikacja karna. Kodeks postępowania karnego. Krótkie komentarze, Warszawa 1998, z. 8.

Grajewski J., Steinborn S., w: Kodeks postępowania karnego, t. 1. Komentarz do art. 1-424, red. L.K. Paprzycki, Warszawa 2013.

Grzegorczyk T., Kodeks postępowania karnego. Komentarz, Kraków 2003.

Grzegorczyk T., Kodeks postępowania karnego, t. 1. Komentarz do art. 1-467, Warszawa 2014.

Grzegorczyk T., Tryby ścigania karnego, w: System Prawa Karnego Procesowego, t. 1. Zagadnienia ogólne, red. P. Hofmański, Warszawa 2013.

Grzeszczyk W., Kodeks postępowania karego. Komentarz, Warszawa 2014.

Hofmański P., Sadzik E., Zgryzek K., Kodeks postępowania karnego, t. 1. Komentarz do artykułów 1-296, Warszawa 2011.

Karaźniewicz J., Wptyw trybu ścigania przestępstw na skuteczność kryminalizacji, w: Granice kryminalizacji i penalizacji, red. S. Pikulski, M. Romańczuk-Grącka, Olsztyn 2013.

Kluza J., Subsydiarny akt oskarżenia w perspektywie nowelizacji kodeksu postępowania karnego - ustawy z 19 lipca 2019 r., Studia Prawnicze i Administracyjne 2019, nr 28 (2).

Kmiecik R., O przyczynach i skutkach kasacji Prokuratora Generalnego z powodu braku skargi uprawnionego oskarżyciela, Prokuratura i Prawo 2014, nr 1.

Kmiecik R., Oskarżyciel positkowy w procesie karnym, Warszawa 1977.

Kruk E., Skarga oskarżycielska jako przejaw realizacji prawa do oskarżania uprawnionego oskarżyciela w polskim procesie karnym, Lublin 2016.

Łagodziński S., Pokrzywdzony jako oskarżyciel positkowy w sprawach publicznoskargowych, Prawo w Działaniu 2008, t. 3.

Misztal P., Strony postępowania, w: MERITUM postępowanie karne, red. D. Świecki, Warszawa 2019.

Paluszkiewicz H., Błaszyk M., Łakomy A., Żbikowska M., Prawne zabezpieczenia przestrzegania zasady legalizmu. Zagadnienia wybrane, w: Zasada legalizmu w procesie karnym, t. 1, red. B. Dudzik, J. Kosowski, I. Nowikowski, Lublin 2015.

Papke-Olszauskas K., Oskarżyciel positkowy w polskim procesie karnym - wybrane zagadnienia, Palestra 2000, nr 1.

Paprzycki L.K., Prawa i obowiązki pokrzywdzonego w postępowaniu przed sądem karnym pierwszej instancji - zarys problematyki, Palestra 2000, nr 2-3. 
Rogacka-Rzewnicka M., Oportunizm i legalizm ścigania przestępstw w świetle wspótczesnych przeobrażeń procesu karnego, Warszawa 2007.

Rogalski M., Procesowe gwarancje zasady legalizmu, w: Zasada legalizmu w procesie karnym, t. 1, red. B. Dudzik, J. Kosowski, I. Nowikowski, Lublin 2015.

Rogoziński P., Kilka uwag na temat przestanek wniesienia subsydiarnego aktu oskarżenia - de lege lata $i$ de lege ferenda, w: Z problematyki funkcji procesu karnego, red. T. Grzegorczyk, J. Izydorczyk, R. Olszewski, Warszawa 2013.

Rydz-Sybilak K., Zasada legalizmu w praktyce organów procesowych a uprawnienia pokrzywdzonego w postepowaniu przygotowawczym, w: Zasada legalizmu w procesie karnym, t. 1, red. B. Dudzik, J. Kosowski, I. Nowikowski, Lublin 2015.

Sikorski A., Przymus adwokacko-radcowski w postepowaniu karnym, Nowa Kodyfikacja Prawa Karnego 2016, t. 41.

Stachowiak S., Gerecka-Żołyńska A., Libertowski P., Żbikowska M., Uwagi o trybach ścigania przestepstw w polskim postepowaniu karnym, w: Z problematyki funkcji procesu karnego, red. T. Grzegorczyk, J. Izydorczyk, R. Olszewski, Warszawa 2013.

Stachurski D., Sądowa kontrola zaniechania ścigania - rzeczywiste czy pozorne wzmocnienie zasady legalizmu w procesie karnym?, Przegląd Sądowy 2012, nr 3.

Stefański R.A., Przeglad uchwat Izby Karnej Sądu Najwyższego w zakresie postępowania karnego za 2013 r., Ius Novum 2014, t. 8, nr 3.

Stefański R.A., Gostyński Z., w: Kodeks postepowania karnego. Komentarz, t. 1, red. J. Bratoszewski, L. Gardocki, Z. Gostyński, S.M. Przyjemski, R.A. Stefański, S. Zabłocki, Warszawa 2003.

Steinborn S., Węzłowe problemy subsydiarnego oskarżenia positkowego, Prokuratura i Prawo 2001, nr 12.

Supera Ł., Wyszkowski D., Subsydiarny akt oskarżenia w ujęciu konstytucyjnym, Palestra 2016, nr 7-8.

Sych W., Wpływ pokrzywdzonego na tok postępowania przygotowawczego w polskim procesie karnym, Zakamycze 2006.

Szołucha S., w: Kodeks postępowania karnego. Komentarz, red. J. Skorupka, Warszawa 2020.

Świecki D., Czynności procesowe obrońcy i pełnomocnika w sprawach karnych, Warszawa 2018.

Troll R., Charakter procesowy pokrzywdzonego przyłaczajacego sie do postępowania na podstawie art. 55 § 3 k.p.k., Przegląd Sądowy 2003, nr 5.

Tylman J., Zasada legalizmu w procesie karnym, Warszawa 1965.

Waltoś S., Nowe instytucje w kodeksie postępowania karnego z 1997 roku, Państwo i Prawo 1997, nr 8.

Waltoś S., Hofmański P., Proces karny. Zarys systemu, Warszawa 2018.

Wiliński P., Proces karny w świetle Konstytucji, Warszawa 2011. 
Wytrykowski K., w: Kodeks postepowania karnego, t. 1. Komentarz. Art. 1-424, red. D. Drajewicz, Warszawa 2020.

Zagrodnik J., Instytucja skargi subsydiarnej w procesie karnym, Warszawa 2005.

Zagrodnik J., Udziat prokuratora w postepowaniu sąowym wszczętym przez oskarżyciela positkowego subsydiarnego, Prokuratura i Prawo 2017, nr 2.

\section{Streszczenie}

Artykuł odnosi się do najważniejszych elementów instytucji oskarżenia subsydiarnego w polskim procesie karnym. Zwrócono uwagę przede wszystkim na procedurę prowadzącą do uzyskania przez pokrzywdzonego prawa do wniesienia subsydiarnego aktu oskarżenia, inne wymogi, których spełnienie warunkuje wejście w tę rolę procesową, oraz relacje pomiędzy oskarżycielem subsydiarnym a publicznym. Wyeksponowano także podobieństwa oskarżyciela subsydiarnego i jego skargi do oskarżyciela prywatnego, podkreślając jednocześnie specyficzne cechy publicznoskargowego trybu ścigania przestępstw. Poszczególne zagadnienia zostały przedstawione $\mathrm{z}$ uwzględnieniem zmian kodeksowych, także nowelizacji z lipca 2019 r. Ocena istniejących rozwiązań została dokonana przede wszystkim z punktu widzenia skuteczności realizacji praw pokrzywdzonego.

Słowa kluczowe: oskarżyciel subsydiarny, posiłkowy akt oskarżenia, postępowanie sądowe, cofnięcie aktu oskarżenia, tryb publicznoskargowy, prokurator, pokrzywdzony

\section{THE PROCEDURAL POSITION OF THE SUBSIDIARY PROSECUTOR - AN ATTEMPT TO ASSESS THE EFFECTIVENESS OF THE PROTECTION OF VICTIMS' RIGHTS IN THE LIGHT OF THE PROVISIONS OF THE CODE OF CRIMINAL PROCEDURE AND ITS AMENDMENTS}

\section{Sum mary}

The article refers to the most important elements of the institution of subsidiary prosecution in Polish criminal trials. Attention is paid primarily to the procedure leading to obtaining the right to lodge a subsidiary indictment, other requirements which must be fulfilled to enter this procedural role, and the relationship between the subsidiary and public prosecutors. Similarities between the subsidiary prosecutor and his complaint and the private prosecutor are also emphasized. Attention is also paid to the specific features of the public-prosecution procedure. Particular issues are presented, including law changes, as well as the July 2019 
amendment of Code of Criminal Procedure. The assessment of polish regulations is made from the perspective of the victims' rights effectiveness.

Key words: subsidiary prosecutor, subsidiary indictment, judicial trial, withdrawal of indictment, public prosecution, public prosecutor, victim

\section{ПРОЦЕССУАЛЬНОЕ ПОЛОЖЕНИЕ СУБСИДИАРНОГО ОБВИНИТЕЛЯ - ПОПЫТКА ОЦЕНКИ ЭФФЕКТИВНОСТИ ЗАЩИТЫ ПРАВ ПОТЕРПЕВШЕГО В КОНТЕКСТЕ ПОЛОЖЕНИЙ УГОЛОВНО- ПРОЦЕССУАЛЬНОГО КОДЕКСА И ЕГО ПОСЛЕДУЮЩИХ ИЗМЕНЕНИЙ}

\section{Резюме}

В статье рассматриваются наиболее важные элементы института субсидиарного обвинения в польском уголовном судопроизводстве. Основное внимание было уделено процедуре, ведущей к получению потерпевшим права предъявить субсидиарное обвинительное заключение, а также другим требованиям, выполнение которых определяет вступление потерпевшим в эту процессуальную роль, как и взаимоотношениям между субсидиарным и государственным обвинителями. Акцентируются сходства субсидиарного обвинителя и его жалобы с институтом частного обвинителя, в то же время подчеркиваются особенности процедуры государственного обвинения при уголовном преследовании. Отдельные вопросы представлены с учетом последующих изменений в кодексе, в том числе изменений от июля 2019 года. Оценка существующих решений производилась в первую очередь с точки зрения эффективности реализации прав потерпевшего.

Ключевые слова: субсидиарный обвинитель, субсидиарное обвинительное заключение, судебное разбирательство, отказ от обвинения, процедура государственного обвинения, прокурор, потерпевший 
